\title{
Environmental Impact Assessment Due to Gas Seepage of Titas Gas Field, Bangladesh
}

\author{
Sujon Kumar Gain, Rafsanjani Rafi, Shimul Hossain ", Rashed Alom Emon, Hossain Al Tanjil, \\ Tanveer Ahmed, Govinda Biswas, Md. Amin Al Anas, Shisher Jalal
}

Department of Petroleum and Mining Engineering, Jashore University of Science and Technology, Jashore, Bangladesh

Email address:

shimulpme@gmail.com (S. Hossain)

${ }^{*}$ Corresponding author

\section{To cite this article:}

Sujon Kumar Gain, Rafsanjani Rafi, Shimul Hossain, Rashed Alom Emon, Hossain Al Tanjil, Tanveer Ahmed, Govinda Biswas, Md. Amin Al Anas, Shisher Jalal. Environmental Impact Assessment Due to Gas Seepage of Titas Gas Field, Bangladesh. Journal of Energy and Natural Resources. Vol. 9, No. 1, 2020, pp. 35-38. doi: 10.11648/j.jenr.20200901.15

Received: November 13, 2019; Accepted: November 29, 2019; Published: February 25, 2020

\begin{abstract}
The biggest gas field of Bangladesh, Titas in Brahmanbaria continues to face a possible disaster due to the seepage of the huge amount of gas mixed with water and oil through thousands of holes and cracks on the surface environment in and around this gas field. Gas is leaking through more than 3,000 big holes, including some 30-ft diameter ones, spreading in paddy fields, water bodies, and the Titas river. Approximately 1000 acres of virgin land with varieties of flora and fauna have been affected through seepage. Soil condition in the villages has degraded and still degrading to such an extent that it becomes unpredictable to comment on how many years it needs to regain fertility. Yet the present alarming situation is rippled with confusion about the actual source of seepage till now. To help the situation, an assessment of the impact of gas seepage from the Titas gas field on the surrounding environment was needed to evaluate the overall environmental condition at present and to propose adequate control measures for the abatement of the adverse impact on the environment. Therefore, the main objective of this research work is to assess the environmental impact of this seepage from the Titas Gas field. To fulfill the object of this study, we have developed a questionnaire including 18 parameters. These parameters encompassed all the aspects of ecology, socio-economic and so on. We visited the study area and made the gathering with affected peoples. The answer to each parameter of the questionnaire has been taken from people. From this study, it is found that all the tube wells of the villages are automatically emitting a huge quantity of natural gas. It is observed that the emitting of gas from the tube wellproduced enormous irritating noise. The air is found polluted in and around the site visited. The most severe and alarming finding the health-related disease (skin disease, asthma, hair fall, water-born diseases e.t.c). It is summarized that about six square $\mathrm{km}$ of the area of Bakail, Suhilpur, Shampur and Anandapur villages, the Titas River and Loiska swamp are at high risk due the seepage.
\end{abstract}

Keywords: Environmental Impact, Gas Seepage, Problem Assessment, Titas Gas

\section{Introduction}

Bangladesh, for being a deltaic plain, is rich in her natural resources. Gas is one of the most important assets of this country. Gas fields of Bangladesh are located in Sylhet, Chatak, Rashidpur, Kailastila, Habigonj, Bharmanbaria, Begumganj and Mulavibajar [1-3]. Among these, the Titas Gas Field is the largest natural gas provider in Bangladesh lies at the outskirts of Brahmanbaria town (Figure 1). Its surroundings include the Titas river and a number of villages with natural beauty. But the present situation cannot support the above information. Because it continues to face a possible disaster due to leakage of a dangerous amount of gas mixed with water and oil through holes and cracks on the ground there. Gas and the thick hot sludge of water and oil are gushing out with increased force now through thousands of cracks and holes on the ground and five-tube well pump at Shampur and Anandapur villages [4-7]. Natural gas with water and petroleum are known as hydrocarbon are automatically streaming out through five-tube well pumps including a new one with huge pressure that makes a roaring 
noise. Similar substances are also gushing out through thousands of holes and cracks in and around the villages and Loiska swamp [8-9]. The water that is gushing out through the leaks is hot and tainted with gas and petroleum. The villagers finding no other alternative source of drinking water are being forced to drink this contaminated water and also cooking and washing with it. All the tube wells of the villages are automatically emitting a huge quantity of natural gas; the air of the village is being polluted creating a severe health crisis in the area (Figure 2). Sometimes when the volume of gas in the air sharply increases, it starts burning if comes in contact with flames of oil- lamps or earthen stoves. Boat rides on the Titas river have also become very risky [1013].

At some places, the gas emitted through some of the holes and cracks is burning with flames leaping high Local residents fear possible devastating incidents of fire there in the upcoming summers as the environmental heat might ignite balls of fire in the air tainted with flammable gas. Residents of the village are now living with a fear of an explosion at any time at the spot. Gas is also leaking through the riverbed of the Titas river and the bed of Loiska Swamp at different spots with roaring sound shaking the ground [1416].

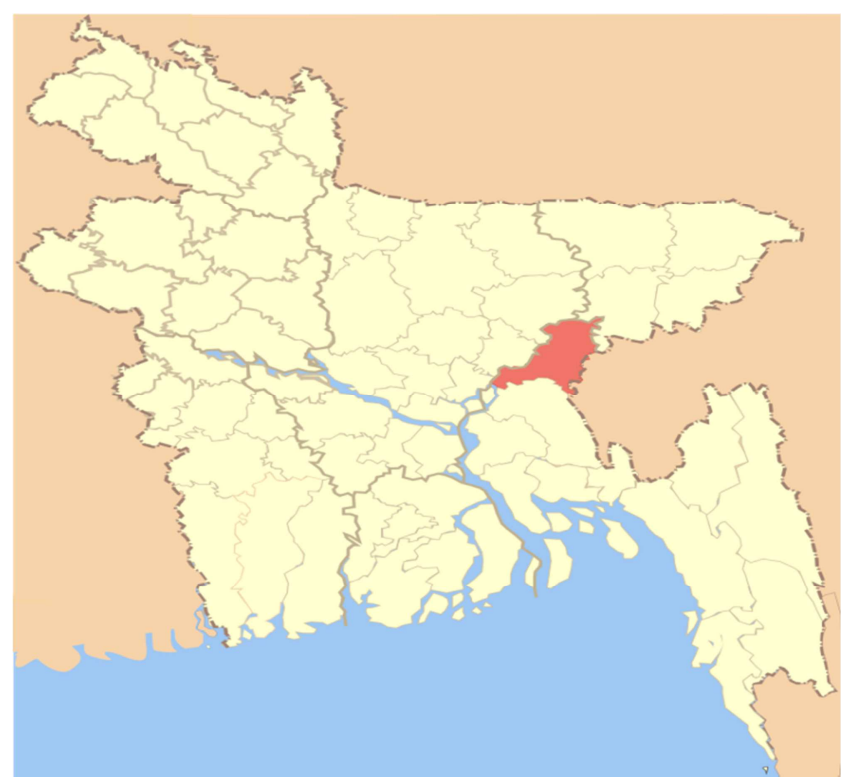

Figure 1. The geographic location of Titas gas field [17].

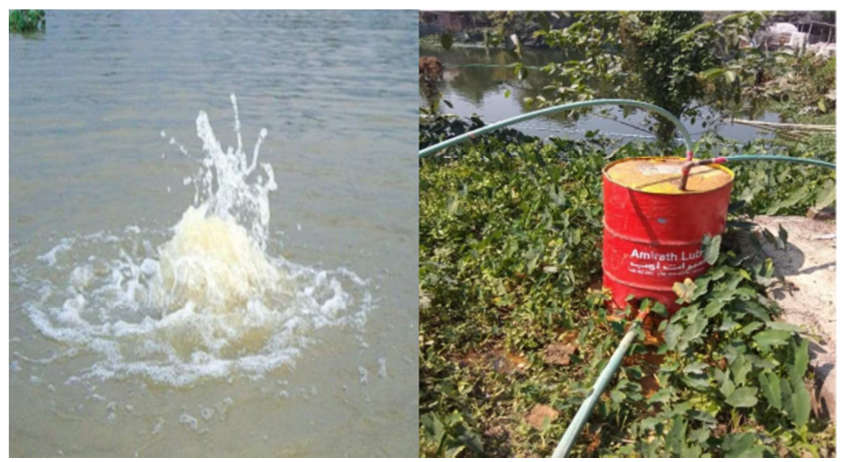

Figure 2. The gas seepage area in Shampur village [18].

\section{Methodology}

Visual observation of the study area was made to get an overall idea about the surrounding existing environment and for the physical observation of the damage caused by the devastating gas seepage as well as in terms of physical observation. EIA methods range from simple to complex, requiring different kinds of data, different data formats, and varying levels of expertise and technological sophistication for their interpretation. In selecting assessment methods, it helps to understand two perspectives underlying the utility of EIA. $3 / 4$ From the first perspective, EIA is a technique to analyze the impacts of project activities and is a complex and complicated procedure. The complexity is increased by the diversity of the disciplines involved social, physical, and biological, populations, development agencies, and project proponents as well as the decision-making process [19].

Checklists are standard lists of the types of impacts associated with a particular type of project. Checklists methods are primarily for organizing information or ensuring that no potential impact is overlooked. They are a more formalized version of ad hoc approaches in that specific areas of impact are listed and instructions are supplied for impact identification and evaluation. Sophisticated checklists include scaling checklists and weighting-scaling checklists (Simple Checklist, Descriptive Checklist, Scaling Checklist).

Modified Graded Matrix (MGM) and Impact Summary Matrix (ISM) (Lohani \& Thanh, 1980) used another grading system. MGM in which relative weights are assigned to each development activity. If the relative priority of development activity is determined, the total value of a particular activity is the sum of the vertical column represented by that in the matrix, multiplied by the priority value. Finally, the total value of all the interactions is the sum of all horizontal values in the matrix. (ISM) is an impact summary matrix that can identify the potential impact areas, predict the impact severity, specify the corresponding mitigation measures, and help in the identification of agencies responsible for implementing mitigation measures. This kind of matrix is simple, covers all the aspects, and provides a complete overview of EIA in summary form. Additionally, it provides an easy guide for decision-makers $[5,11]$.

\section{Result and Discussion}

\subsection{The Environmental Condition Before Seepage Incursion}

To assess the impact of gas seepage at the Titas gas field on various environmental issues, numerous field visits have been made to the gas field sites and on the surrounding environment to observe the changes that occurred to the surrounding environment. Trees, plants, local components, and other habitats have used as bioindicators to signify the environmental impacts. During field visits, some photographs have been taken and local people have been interviewed regarding the environmental consequences. The assessment of environmental impacts on the surrounding environment of 
the "Titas gas field" can be described into three steps such as environmental conditions before seepage incursion, identification of impact on various environmental sectors and assessment of impact [10].

Settlement: The 'Titas gas field' is situated mainly in Suhilpur and Majlishpur union beside 'Comilla, Brahmanbaria, Sylhet Highway' (Old C and B road)' road. Before the establishment of the gas field in 1968 the total area was treated as agricultural land covered with many trees and bushes situated on the bank of the Titas river. It was not a residential or commercial place.

Wildlife: Various kinds of animals such as fox, wild hen were available before the establishment of the gas field. There was a green belt of trees which was replaced by the installment of the oil and gas development project. Since then the biodiversity of the area continued depletion. But the situation was not too rusty before the seepage intrusion (Figure 3). It was a resident for the birds as the area consists of several marshy or swampland. Migratory birds usually found in that area during winter. Various kinds of reptiles were present there. The fishery was one of the most popular businesses in the local community.

Agriculture: The fertility of the land of that area was good enough to support agricultural development. The soil condition was perfect for the production of rice, wheat, and other vegetables as there was plenty of water. Basically, the paddy field covers the highest preference by the local people. But after started gas seepage on the area the soil fertility condition is very low (Figure 4).

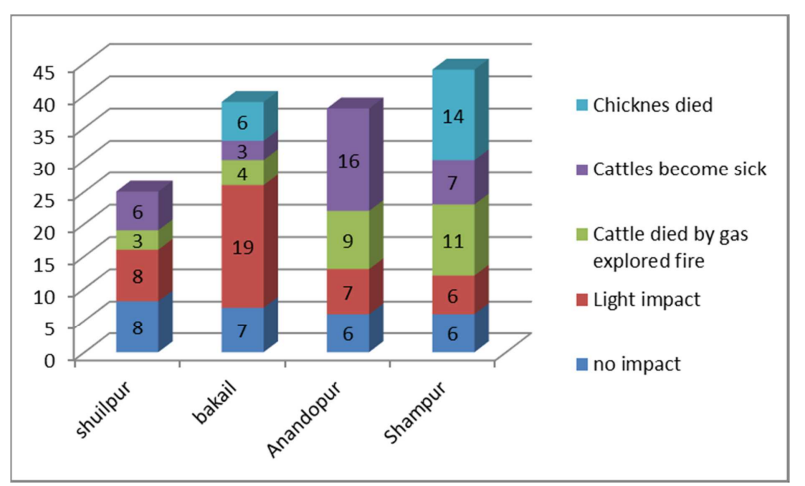

Figure 3. Graphical view of impact on animal husbandry of the surveying area.

Impact on fertility of agricultural land

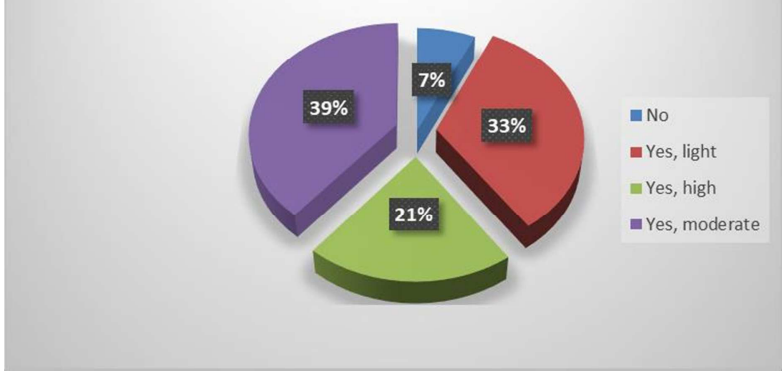

Figure 4. Graphs of impact on fertility of agriculture land of the surveying area.
Surface and groundwater: The source of surface water was several ponds present there and the river. People used that water for their domestic purposes. The quality of surface water was quite good and plenty of fishes were available on that water system. The main source of groundwater of that locality was a few no of tube wells placed in the villages by the corresponding Union Parishad. The quality of the water for drinking purposes was good enough that was investigated by the field survey.

Infrastructure: There was no infrastructure present there. Some tin shed buildings, a mosque, the school are the main structures of the villages. There was also some brick-built buildings were present there.

Human resource: Before the establishment of the gas field there was a limited human habitation at that time. The surrounding population was mainly engaged in agriculture and fishery. The surrounding population can be mainly the villagers of the villages named Bakail, Anondopur, Shampur, Kholapara (Suhilpur). There is a brickfield near to the No. 3 gas field situated at the end of the well No. 3 road. So the labors who work on that brickfield live near to the gas field.

\subsection{Findings of Checklist Method}

Ecological Parameters: According to the checklist the fisheries, migratory bird, swampland, tree plantation/cutting trees, wetlands are identified as key issues that require detailed and in-depth further investigation and the main focus in the project activities. The parameter named migratory bird does not fall into key issue criteria.

Physicochemical parameters: The checklist also identifies the key issues which fall into this category. Erosion\& siltation, drainage congestion and waterlogging, Soil characteristics/soil fertility, flood control and drainage, groundwater table, water pollution, air pollution/noise pollution were identified as a key issue. Only the obstruction to wastewater now was escaped from the key issue.

Socio-economic parameters: Public property, human workability, health and nutrition, loss of agricultural land, employment opportunities, irrigation facility, animal husbandry, effect on children, roadway condition needs further investigation. Here physical fitness and commercial and service facility does not support the key issue criteria.

\subsection{Findings of Matrix Method}

Ecological Parameters: According to the matrix, the ecological parameter is on a negative severe condition which is alarming and needs more concentration of the authority. The fishery was in the worst condition and near to the extinguishing point.

Physico-chemical parameters: It shows a position of negative moderate. More Emphasis should be given to the loss of agricultural land.

Socio-economic parameters: It is the lowest affected criteria on the context of these parameters and stays a position of negative low. The total environmental achievement shows negative moderate impact since all the 
parameters show the impacts of negativity.

\section{Conclusion}

The main focus of the study was to investigate the Environmental Impacts through seepage and industrial discharge and evaluation of the degradation of various environmental parameters due to these criteria. The EIA of the study area gives an overall idea about the impacts on the socio-economic status of the respondents as well as the people affected by seepage and the biodiversity change of the affected area. People are using free gas for cooking and energy purpose, as it is extremely dangerous if any incident due to fire takes place. So some strict regulations should be made by the gas field authority to help the situation. Another striking feature is that the groundwater table has risen to such an extend so that water can be found at a depth of 3 meters below the surface.

\section{References}

[1] American Public Health Association, Water pollution control Federation, (APHA, AWWA, WPFC) [1985]; The standard methods for the examination of water and wastewater; 16th Edition.

[2] Sadler \& Fuller et al (2002) contained in Fuller, K. et al (2004), Guidelines for Environmental Impact Assessment, IEMA, Lincoln.

[3] Brian Oram, PG, Monitoring the Quality of Surfacewaters, http://www.waterresearch.net/watrqualindex/.

[4] Sourov Datta Bijoy, Md. Yousuf Gazi, S. M. Mainul Kabir, Badrul Imam (2019); Geological And Geophysical Observations To Determine The Gas Seepage Source Of Titas Gas Field Region, Bangladesh; J. Asiat. Soc. Bangladesh, Sci. 45 (1).

[5] Chilingarian. O, Robertson. V. J, and Kumar S. et al (1989). Surface Operations in Petroleum.

[6] Production II. Developments in Petroleum Science Elsevier,
Amsterdam. 562 pp. Chapman R. E, 1983. Petroleum Geology. Elsevier. Amsterdam, pp. 245-251.

[7] Curtis \& Tompkins, Ltd. (July 2007), GENERAL CHEMISTRY, STANDARD REPORTING LIMITS.

[8] Doligez, B. (Editor), 1987. Migration of Hydrocarbons in Sedimentary Basin. 2nd IFP Explor. Res. Conf., Carcans France, Gulf Publ. Co., Houston, Tex.

[9] Department of Environment (DOE) [1991]; Environmental quality standards for Bangladesh; Government of the Republic of Bangladesh.

[10] Bhattacharjee. D, (March 2006), B. Sc. Engg. Thesis, "An Assessment of the impact of devastating gas explosion in Magurchara Gas Field, on surrounding environment", Department of Civil and Environment Engineering, SUST, Sylhet.

[11] Morshedur Rahman, Sm Mainul Kabir, Badrul Imam, AKM Eahsanul Haque, Md. Al Amin (2019); Occurrence, distribution, and origin of shallow biogenic gas in late quaternary unconsolidated sand deposit of shahbazpur structure, Southern Bangladesh; Petroleum and Coal 60 (6).

[12] EIA for Developing Countries, Chapter 3: Methodology of EIA, (December 1997).

[13] Peavy. H S, Rowe. D R, Tchobanoglous. G et al (1985), Environmental Engineering, McGraw - Hill International Editions. pp. 55.

[14] Joint E\&P Forum/ UNEP Technical Publication. Environmental management in oil and gas exploration and management.

[15] Ahmed. M F, Jahan. H et al. ITN BUET, Participatory Management of low cost water supply and sanitation. pp. 4142.

[16] Nelson, E. B., 1990. Well Cementing, Developments in Petroleum Science 28, Elsevier, Amsterdam, 496 pp.

[17] Practical Work on Environmental Impact Assessment, 622M2700, Textbook: Canter, L. W.

[18] Environmental Impact Assessment, 1996, McGraw-Hill.

[19] Sadler, B., Fuller, K., et al (2002), UNEP Environmental Impact Assessment Training Resource. 